\title{
ARTERIAL BLOOD GASES AND ACID-BASE BALANCE IN NORMAL CHILDREN ${ }^{1}$
}

\author{
By DONALD E. CASSELS AND MINERVA MORSE 2
}

(From the Department of Pediatrics, University of Chicago Clinics, Chicago, Illinois)

(Submitted for publication April 16, 1953; accepted May 15, 1953)

Robinson (1) studied the effect of age on the arterial blood gases and the acid-base balance of normal males from 5 to 91 years of age. In addition to the well known increase in oxygen combining capacity which occurs during childhood and adolescence, Robinson found moderately lower mean values for hemoglobin saturation in adults above 40 years of age, and slightly higher mean values for arterial $\mathrm{CO}_{2}$ content and $\mathrm{CO}_{2}$ tension in adults as compared with children. In the case of the alkaline reserve, mean values varied between 21.2 and 22.2 millimols per liter for all age groups except the youngest. Robinson found unusually low values of alkaline reserve in children 4 to 6 years of age. The present study was undertaken to supplement the work of Robinson in the years of childhood and adolescence, in order to establish more firmly the range of variation that may be expected in healthy children, and to provide a basis for the study of arterial blood gases and acid base balance in disease.

\section{MATERIAL}

The subjects of the study were drawn from three sources:

1. Children of 10 years and younger were of both sexes. They had been carefully selected from patients at Bobs Roberts Memorial Hospital as representing physiologically normal states at the time the blood samples were drawn. Breakfast was withheld and the child was kept in bed until after the sample was taken.

2. Subjects between 11 and 17 years of age were normal healthy boys ${ }^{3}$ who came to the laboratory to participate in various tests for physical fitness. The results of most of these tests have been described earlier (2-5).

1 This work was conducted under a grant from the Douglas Smith Foundation at the University of Chicago.

2 Present Address: Bobs Roberts Memorial Hospital, 920 East 59th St., Chicago 37, Ill.

8 We are indebted to the University of Chicago Settlement House, the Valentine Boys Club, the Hyde Park Neighborhood House and friends for their kindness and interest in sending these boys to the laboratory for the tests.
The boys came to the laboratory in the early morning, without breakfast, and had been resting in the recumbent position for approximately two hours before the arterial blood sample was drawn.

3. Nine male medical students were also included in the study. Blood samples were drawn approximately two hours after breakfast and after rest in the recumbent position for 15 to 30 minutes.

\section{METHODS}

Arterial samples were drawn from the brachial artery in the adults and older children and from the femoral artery in younger children. They were drawn without local anesthetic and usually with little discomfort to the subject; however, breathholding could not always be avoided, and in the younger children crying usually occurred.

The samples were drawn into syringes whose dead space was filled with heavy mineral oil. The blood was transferred immediately, either under oil into centrifuge tubes containing $1 \mathrm{mg}$. heparin (Connaught Laboratories) dissolved in $0.02 \mathrm{ml}$. saline, thence, without contact with air, into sampling tubes containing mercury; or directly into sampling tubes containing $0.02 \mathrm{ml}$. of the heparinsaline solution above the mercury. The latter technique was used in the later studies which included most of the adults and children under 11 years of age. The samples were kept in ice water in a refrigerator until analysis was completed.

The oxygen and carbon dioxide contents of the arterial blood samples were determined by the manometric method of Van Slyke and Neill (6), using $0.5 \mathrm{ml}$. samples. The determinations were performed in duplicate, or until good checks were obtained. The oxygen and carbon dioxide contents were also determined after the blood sample had been equilibrated for 20 minutes at $37^{\circ} \mathrm{C}$. in tonometers of approximately $325 \mathrm{ml}$. capacity which contained carbon dioxide at an approximate tension of $40 \mathrm{~mm}$. $\mathrm{Hg}$ and oxygen at $185 \mathrm{~mm}$. Hg. Oxyhemoglobin $\left(\mathrm{HbO}_{2}\right)$ content and capacity were determined by subtracting the appropriate amount for physically dissolved oxygen from the oxygen content of the blood as drawn and of the blood after equilibration respectively. Percentage oxygen saturation was calculated from $\mathrm{HbO}_{2}$ content and $\mathrm{HbO}_{2}$ capacity. No correction was made for the errors in oxygen capacity measurements which Roughton, Darling and Root (7) have shown may be introduced by the tonometer method. From the blood data and the gas contents of the tonometer, determined by Haldane analy- 
sis, alkaline reserve $\left(\mathrm{T}_{40}\right)$ of blood and serum, $\mathrm{CO}_{2}$ tension $\left(\mathrm{pCO}_{2}\right)$, and serum bicarbonate concentration $\left(\mathrm{BHCO}_{3}\right)$, were calculated by methods developed at the Harvard Fatigue Laboratory (8). The $\mathrm{pH}_{\mathrm{s}}$ was calculated using the Henderson-Hasselbalch equation.

In 64 older children, 10 to 17 years of age, additional analyses were made in order to describe the acid-base or electrolyte balance of the plasma more completely. These included plasma protein, chloride, phosphorus, lactic acid and sodium. The methods used were: for protein, determination of total nitrogen by a modification of the micro Kjeldahl method described by $\mathrm{Ma}$ and Zuazaga (9) and calculation as protein by multiplying by the factor 6.25 (after correction for non-protein nitrogen); for chloride, the silver iodatethiosulfate titrimetric method of Sendroy (10), using $0.1 \mathrm{ml}$. samples; for phosphorus, an adaptation of the method of Fiske and Subbarrow (11) to $0.2 \mathrm{ml}$. samples, with the aid of the Evelyn colorimeter; for lactic acid, a modification by Edwards (12) of the method of Friedemann, Cotonio and Shaffer (13), using $0.5 \mathrm{ml}$. of whole blood; for sodium, a modification by Consolazio and Dill (14) of the method of Butler and Tuthill (15). The base equivalence of protein, or proteinate ion concentration, was calculated from the equation of Van Slyke, Hastings, Hiller and Sendroy (16), milliequivalents of base bound by protein = $0.104 \times$ grams protein $\times\left(\mathrm{pH}_{2}-5.08\right)$, and of phosphate, by assuming a valence of 1.8 .

\section{RESULTS}

After plotting the individual results against age, as in Figure 1, the ages which showed a similar range of variation were grouped together and the mean and standard deviation of each group was determined. The significance of differences between the means of successive groups was determined by Fisher's test. The results are given in Table I. The ranges of normal variation, defined as \pm 2 standard deviations from the mean, are shown graphically in Figure 1. Several age groupings which did not prove to be significantly different from preceding or following groups were retained because the narrower ranges of variation secured for some groups by this means appeared to define better the range of normal variation.

The results indicate that $\mathrm{HbO}_{2}$ capacity varies little with age between 3 and 14 years. Above 14 years the $\mathrm{HbO}_{2}$ capacity level rises; the mean value of 19.7 vol. per cent for boys of 15 to 17 years is, however, significantly below the mean of 21.2 vol. per cent which was found for the adult group of this study.

The arterial blood of younger children appears to be slightly less saturated with oxygen than that of older children and adults. A mean percentage saturation of 94.2 per cent for children of 2 to 4 years is significantly lower than that of 95.8 per cent for children of 7 to 17 years $(t=3.5)$; the mean of 95.3 per cent for children of 5 and 6 years lies between those of the younger and older groups. The lower mean value for the youngest group is due chiefly to values of approximately 92 per cent in three children of 3 and 4 years, and to the fact that the younger children did not show saturation levels above 97 per cent, such as were observed frequently in the older children. Values for boys of 14,15 and 16 years varied more widely than those for younger children and adults.

In the case of arterial blood $\mathrm{CO}_{2}$ content $\left(\mathrm{CO}_{2}\right)_{b}$ and serum bicarbonate $\left(\mathrm{BHCO}_{3}\right)_{\text {, dif- }}$ ferences between age groups above 6 years did not prove to be significant, but the groupings were retained in order to represent adequately the trend toward higher values which begins after 10 years. Analysis of data for the children between 10 and 17 years gave correlation coefficients of 0.306 for $\left(\mathrm{CO}_{2}\right)_{b}$ with age, and 0.398 for $\left(\mathrm{BHCO}_{3}\right)_{\mathrm{s}}$ with age. These values are significant at better than the 1 per cent level.

Values of alkaline reserve of the blood $\left(T_{40}\right)_{b}$ show no definite trend with age between 7 and 17 years, but a mean of $46.4 \mathrm{vol}$. per cent for this age group is significantly lower than that for the adults of this study, 47.9 vol. per cent. With the exception of three values which are low, children of 4 to 6 years gave values of $\left(T_{40}\right)_{b}$ which approximate those of older children, but children of 2 and 3 years had much lower values as a rule. With the exception of one high value of $49.2 \mathrm{vol}$. per cent, $\left(T_{40}\right)_{b}$ ranged between 34.9 and 43.3 vol. per cent in these young children.

The same trends with age that characterize $\left(T_{40}\right)_{b}$ values apply in general to corresponding $\left(T_{40}\right)_{8}$ values. However, in the case of $\left(T_{40}\right)_{8}$ a trend toward higher values occurred at 14 years. A difference of 1.1 vol. per cent between the means of the 7 to 13 year and the 14 to 17 year groups is probably significant. This trend appears to have been masked in the case of $\left(T_{40}\right)_{b}$ by the higher red cell volume of the older group, for the $\mathrm{CO}_{2}$ concentration in the cells is lower than that in the serum.

The $\mathrm{pCO}_{2}$ of arterial blood shows wide variation in our data. A mean $\mathrm{pCO}_{2}$ of $41.3 \mathrm{~mm}$. $\mathrm{Hg}$ 

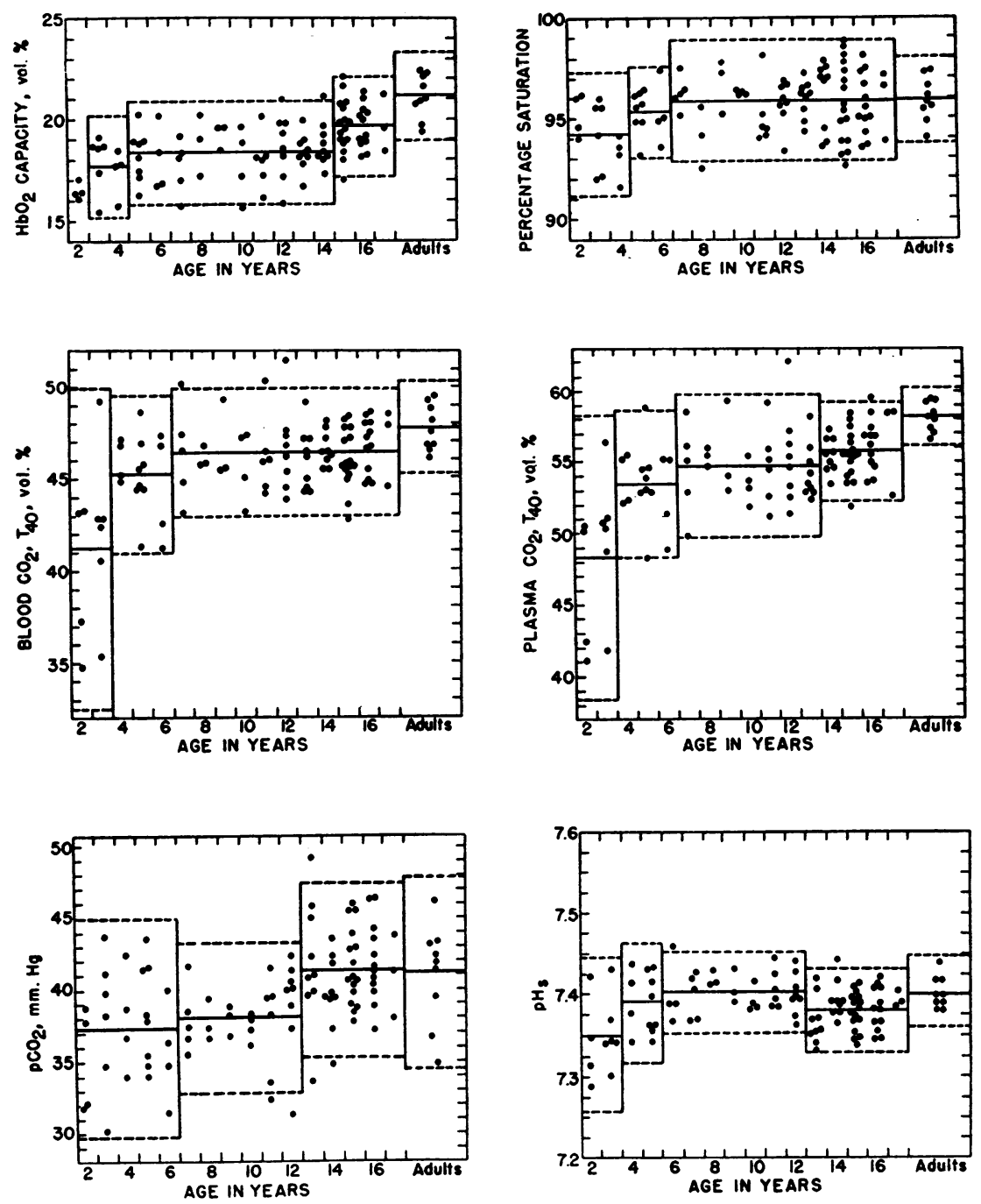

Fig. 1. Relation of Age to the Blood Gas Concentrations and the Acid-base Equilibrium in the Arterial Blood of Normal Chimdren

Data for each child are plotted according to the age of the child. The solid horizontal lines represent the mean value for age groups which show similar trends. The broken lines inclose the range of normal variation as defined by \pm 2 standard deviations from the mean of each group. Data for 9 young male adults are included for comparison. Blood $\mathrm{CO}_{2} \mathrm{~T}_{40}$, or alkaline reserve, is defined as the $\mathrm{CO}_{2}$ content of fully oxygenated blood which has been equilibrated at $37^{\circ} \mathrm{C}$. with excess $\mathrm{O}_{2}$ and with $\mathrm{CO}_{2}$ at a tension of $40 \mathrm{~mm}$. $\mathrm{Hg}$. Plasma $\mathrm{CO}_{2} \mathrm{~T}_{40}$ was calculated from blood $\mathrm{CO}_{2}$ $T_{40}$, using a line chart (8) which takes $O_{2}$ capacity into acount.

for children of 13 to 17 years is very close to that of the adults, $41.1 \mathrm{~mm}$. Hg. It is significantly higher than the mean values for younger children, $37.3 \mathrm{~mm}$. $\mathrm{Hg}$ for children 1 to 6 years old and 38.0 $\mathrm{mm}$. $\mathrm{Hg}$ for those of 7 to 12 years old.

With few exceptions the arterial $\mathrm{pH}_{\mathrm{s}}$ values found in this study fall within the limits generally accepted as normal, 7.35 to 7.45 . The 2 to 3 year group, with a mean $\mathrm{pH}_{\mathrm{s}}$ of 7.35 and with three values below 7.32, constitutes a notable exception. In the other age groups variations in distribution occur, with the 4 to 5 year and the 13 to 17 year groups tending to show lower $\mathrm{pH}_{\mathrm{s}}$ values than both the children of 7 to 12 years and the adults. The mean $\mathrm{pH}_{\mathrm{s}}$ of 7.38 for boys of 13 to 17 years is significantly lower than the mean of 7.40 for the children of 6 to 12 years and the adults. It is puzzling to note that Robinson (1) 
found a higher $\mathrm{pH}_{\mathrm{s}}$ value for adolescents than for other age groups of his study.

The acid-base balances for the various age groups of our study are represented graphically in Figure 2 in which $\left(\mathrm{BHCO}_{3}\right)_{8}, \mathrm{pCO}_{2}$ and $\mathrm{pH}_{8}$ are plotted simultaneously by means of triaxial coordinates, according to the method of Hastings and Steinhaus (17) and of Shock and Hastings (18). In such charts the range of normal variation is customarily represented by a regular hexagon in the center. In the charts of Figure 2 the center represents the mean for 21 normal adults. This number includes the 9 adults of our study and 12 adult males studied by Dill, Edwards and Consolazio (19) by the same methods. The irregular hexagon around the center is bounded by lines which represent \pm 2 standard deviations from the mean $\left(\mathrm{BHCO}_{3}\right)_{\mathrm{s}}, \mathrm{pCO}_{2}$ and $\mathrm{pH}_{\mathrm{s}}$ of the 21 normal adults. Thus the results for each age group may be compared readily with the acidbase balance of the normal adult.

In the youngest age group, 2 to 3 years, the displacement of the acid-base balance from the adult pattern is almost entirely in the direction of fixed acid excess or metabolic acidosis. In both the 4 to 6 year group and the 7 to 11 year group there is still evidence of metabolic acidosis as judged by adult standards, but to a lesser degree than in the very young children. The acid-base pattern in these groups, however, tends to be shifted to the right in the direction of $\mathrm{CO}_{2}$ deficit or respiratory alkalosis, the net effect producing a normal $\mathrm{pH}_{\mathrm{s}}$, but often a slightly low $\left(\mathrm{BHCO}_{\mathrm{s}}\right)$. and $\mathrm{pCO}_{2}$. As age increases beyond 11 years the

TABLE I

Effect of age upon the blood-gas concentrations and acid-base equilibrium of arterial blood

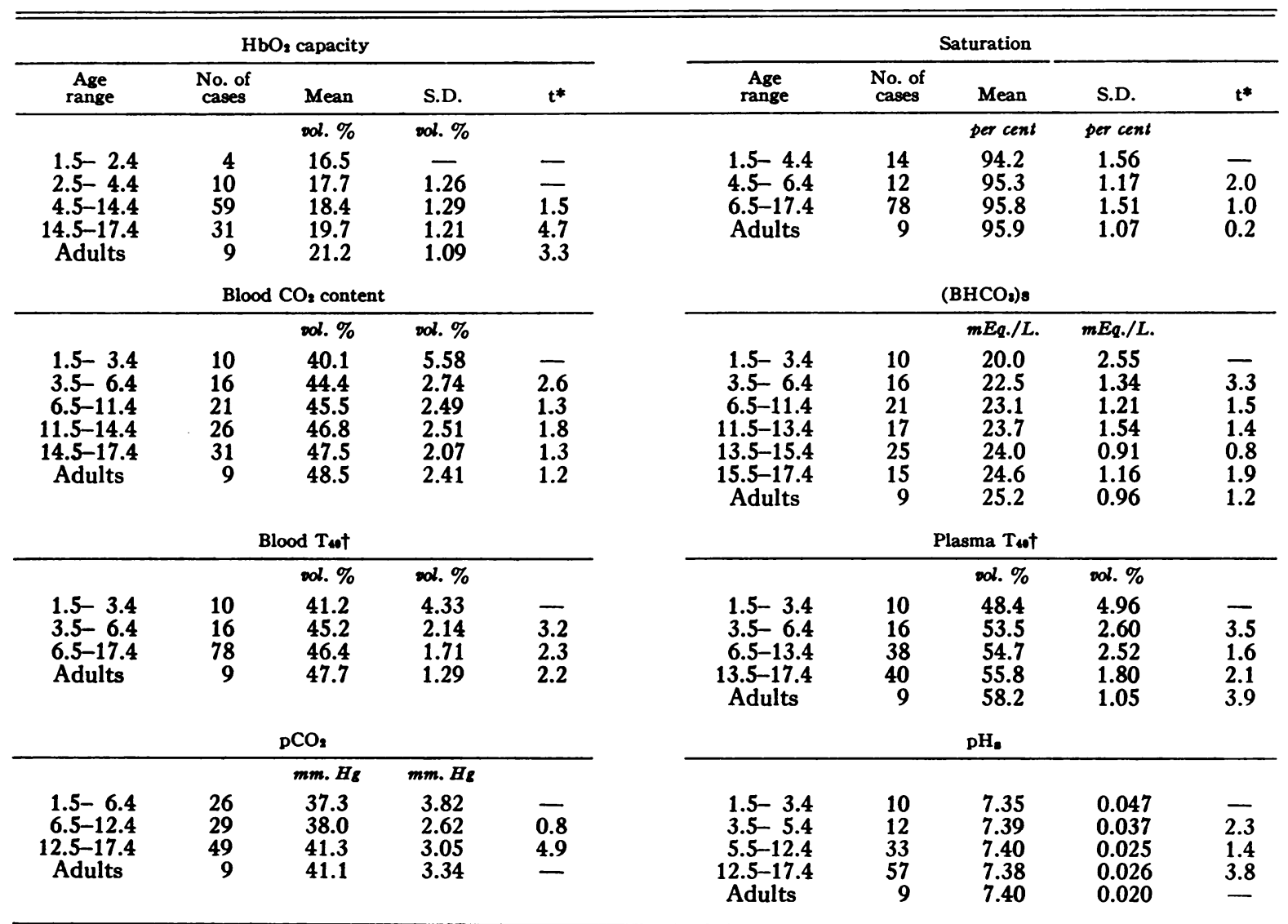

* The $t$ score measures the significance of the difference between a given mean and the mean immediately preceding.

$\dagger T_{40}$, or alkaline reserve of the blood, is defined as the $\mathrm{CO}_{2}$ content of oxygenated blood equilibrated at $37^{\circ}$ at a $\mathrm{CO}_{2}$ tension of $40 \mathrm{~mm}$. Hg. $\mathrm{T}_{40}$ of the plasma was calculated from blood $\mathrm{T}_{40}$, using a line chart which takes into account $\mathrm{rHCO}$ and $\mathrm{O}_{2}$ capacity (8). 


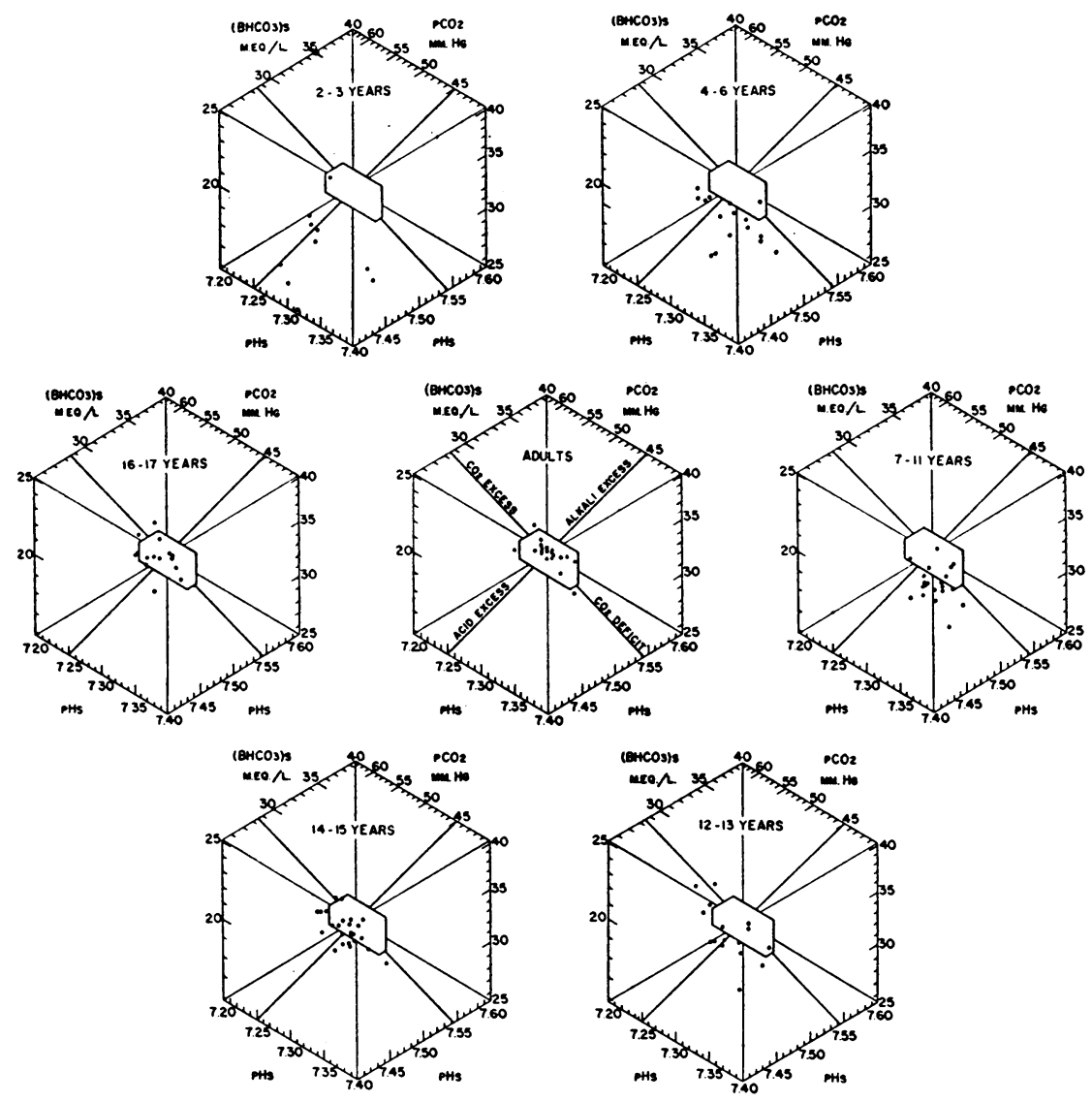

Fig. 2. Serum Bicarbonate, $\mathrm{CO}_{2}$ tension, and pH, in the Arterial Blood of Children of Various Age Groups

The data are plotted on triaxial coordinates according to the method of Hastings and Steinhaus (17). In the adult group the values represented by open triangles were taken from a study of the arterial blood of 12 normal adults by Dill, Edwards and Consolazio (19). The hexagon in the center of each chart incloses the area of normal variation for adults as defined by \pm 2 standard deviations from the mean serum bicarbonate, $\mathrm{pCO}_{2}$ and $\mathrm{pH}_{\mathrm{s}}$ for 21 normal male adults, 9 from the present study and 12 from the study of Dill, Edwards, and Consolazio (19).

TABLE II

Serum electrolyte concentrations in the arterial blood of normal boys 10 to 17 years of age*

\begin{tabular}{|c|c|c|c|c|c|c|c|c|}
\hline Age & $\begin{array}{l}\text { No. of } \\
\text { cases }\end{array}$ & Bicarbonate & Chloride & Proteinate & $\begin{array}{c}\mathrm{HCO}_{2}^{-}+\mathrm{Cl}^{-} \\
+ \text {Prot. }\end{array}$ & Phosphate & Lactate & Sodium \\
\hline$y r$. & & $m E q . / L$ & $m E q . / L$ & $m E q . / L$ & $m E q . / L$ & $m E q . / L$ & $m E q . / L$ & $m E q . / L$. \\
\hline $10-12$ & 11 & $\begin{array}{c}23.0 \\
(20.7-24.9)\end{array}$ & $\begin{array}{c}104.2 \\
(99.4-107.6)\end{array}$ & $\begin{array}{c}16.7 \\
(14.6-19.4)\end{array}$ & $\begin{array}{c}143.9 \\
(141.3-146.0)\end{array}$ & $\begin{array}{l}2.55(10) \\
(2.25-3.05)\end{array}$ & $\begin{array}{c}1.5 \\
(0.6-2.1)\end{array}$ & $\begin{array}{c}141.1(8) \\
(136.4-143.8)\end{array}$ \\
\hline $13-14$ & 20 & $\begin{array}{c}23.7 \\
(21.6-26.0)\end{array}$ & $\begin{array}{c}104.3 \\
(101.4-107.6)\end{array}$ & $\begin{array}{c}16.7 \\
(14.9-18.3)\end{array}$ & $\begin{array}{c}144.7 \\
(142.7-146.8)\end{array}$ & $\begin{array}{c}2.61(12) \\
(2.10-3.05)\end{array}$ & $\begin{array}{c}1.6 \\
(0.9-2.8)\end{array}$ & $\begin{array}{c}140.3(12) \\
(136.2-143.4)\end{array}$ \\
\hline $15-17$ & 33 & $\begin{array}{c}24.3 \\
(22.2-27.0)\end{array}$ & $\begin{array}{c}104.3 \\
(100.0-107.5)\end{array}$ & $\begin{array}{c}17.2 \\
(15.4-19.0)\end{array}$ & $\begin{array}{c}145.9 \\
(142.4-149.9)\end{array}$ & $\begin{array}{c}2.45(29) \\
(1.91-3.07)\end{array}$ & $\begin{array}{c}1.5 \\
(0.9-2.8)\end{array}$ & $\begin{array}{c}141.0(24) \\
(136.6-145.5)\end{array}$ \\
\hline Adult $\dagger$ & 12 & $\begin{array}{c}25.1 \\
(23.9-26.0)\end{array}$ & $\begin{array}{c}104.6 \\
(103.7-105.7)\end{array}$ & $\begin{array}{c}17.4 \\
(15.9-18.3)\end{array}$ & $\begin{array}{c}147.1 \\
(144.8-149.6)\end{array}$ & & $\begin{array}{c}1.4 \\
(1.2-1.9)\end{array}$ & $\begin{array}{l}140.0 \\
(131.9-143.1)\end{array}$ \\
\hline
\end{tabular}

* The upper value in each case represents the mean, and quantities below in parentheses, the range of variation. In the case of phosphate and sodium, numbers in parentheses to the right of the mean indicate the number of cases included in the mean.

$\dagger$ Data taken from a study by Dill, Edwards and Consolazio (19). 
degree of metabolic acidosis decreases, and many of the cases in the 12 to 13 year and 14 to 15 year groups fall within the normal range of variation. Their values, however, tend to be shifted farther to the left, in the direction of $\mathrm{CO}_{2}$ excess. At 16 to 17 years the adult pattern of acid-base equilibrium appears to be fairly well established, although a tendency toward $\mathrm{CO}_{2}$ excess persists.

The electrolyte balance of the serum for the arterial blood of boys 10 to 17 years of age, is given in Table II and is compared there with similar data obtained from the results of a study of 12 normal adult males by Dill, Edwards and Consolazio (19). The results indicate that there is a gradual rise in the serum bicarbonate concentration as the child passes through adolescence. This rise in bicarbonate is not compensated by a corresponding reduction in chloride, proteinate, phosphate or lactate ions, nor by an increase in the sodium ion. We have found no evidence in the literature to suggest a compensating increase in the other basic ions, potassium, calcium and magnesium, during the transition from childhood to adulthood. The compensation for the rise in serum bicarbonate which occurs as the age of the child increases would, therefore, seem to lie in a reduction in concentration of one or more as yet undetermined anions, probably organic in nature.

\section{DISCUSSION}

The present report is one of the few studies of hemoglobin levels in children in which hemoglobin concentration in the blood has been measured by determination of the oxygen capacity of the blood by the Van Slyke method. Previous studies include those of Mugrage and Andresen $(20,21)$ for Denver children, which are believed to show higher values than those for the United States as a whole because of a compensatory reaction to high altitude, and that of Robinson (1) which includes data for about 25 children of the Boston area. Most other studies have used colorimetric or photometric methods which, for lack of a pure hemoglobin solution, usually have been calibrated against solutions whose hemoglobin concentrations have been measured by oxygen capacity or blood iron determinations. A mass study of the population in Hessen, Germany (22), employed the copper sulfate specific gravity method which was standardized against Van Slyke oxygen capacity determinations.

A summary of various hemoglobin studies that have been made in the United States, Canada, Great Britain, Germany and Australia (1, 20-37) is given in Figure 3. It is evident that there is little agreement concerning the normal hemoglobin level of a child of a given age and the changes with growth. In general it is recognized that after a low level, reached during the first half year or year of life, the hemoglobin level rises at rates depending upon the age of the child, and reaches the adult level at an age which as yet is not too clearly defined. It is now known that much of the confusion which exists is due both to technical errors and to the great complexity of factors which effect the hemoglobin level. This question has been well discussed in Chapter II of the report of the British Committee on Hemoglobin Surveys (26).

For children up to 12 years, and for the adult group, the hemoglobin levels of our study ${ }^{4}$ approximate the higher hemoglobin levels reported in the literature for the various ages. On the other hand, between 13 and 17 years our values are lower than most of those of other studies, especially at 14,16 and 17 years. Variation in the resting period prior to drawing the blood sample in the three groups of subjects may in part explain this discrepancy. Most of the subjects from 11 to 17 years of age had remained in the recumbent position for two hours or more prior to the drawing of the arterial blood sample, for measurements of lung capacity and of blood and available fluid volumes, while the younger children and the young adults had been in the recumbent position fifteen to thirty minutes when the sample was drawn. In the case of the younger children, furthermore, a complete resting state could not be maintained in the period preceding and during the taking of the sample. The effect of rest and posture on the plasma volume is well known. Recently Widdowson and McCance (39) showed that after two hours rest in bed the mean hemoglobin concentration decreased from 14.1 to $13.4 \mathrm{gm}$. per $100 \mathrm{ml}$. of blood.

1 Hemoglobin concentrations, in grams per $100 \mathrm{ml}$. blood, were calculated by dividing $\mathrm{HbO}_{2}$ capacity values in vol. $\%$ by 1.34 . 


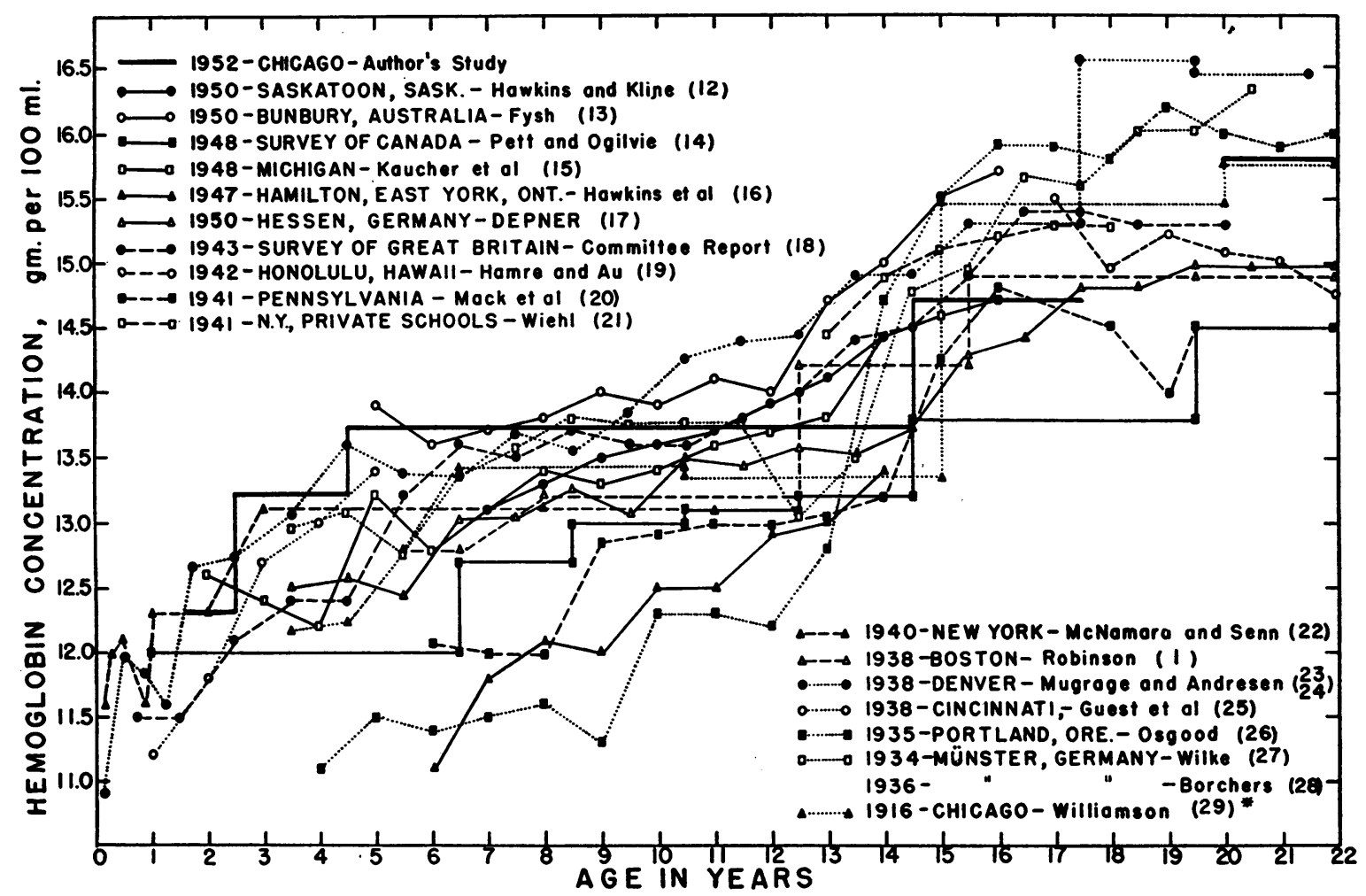

Fig. 3. Relation of Age to the Hemoglobin Concentration of the Blood in Chindren and Young Male Adults -A Comparison of the Author's Results with Those of Other Studies in the United States, Great Britain, Canada, Australia, and Germany

With three exceptions the values shown on the chart include data for children and young adults of the male sex. These exceptions are 1) the author's study which includes data for children of both sexes under 11 years, 2) the study of McNamara and Senn (30) which gives data for infants and children of both sexes through 11 years, and 3) that of Guest, Brown and Wing (33) which gives data for both sexes from infancy through 5 years.

Williamson's original values are generally believed to be too high, due probably to the use of impure hemoglobin as the standard for a spectrophotometric method. Following the example of Peters and Van Slyke (38), the original mean values have been reduced by multiplying each by 0.92 .

Since oxygen capacity was determined by the gasometric method without correction for the errors which Roughton, Darling and Root (7) showed may be introduced by unequal drainage of cells and plasma from the walls of the tonometer and by the presence of inactive hemoglobin, the mean value of 95.9 per cent for the arterial saturation of normal adults is approximately 2 per cent lower than the recent results of Drabkin and Schmidt (40), Comroe and Walker (41), and Wood (42). Earlier determinations (1, 4349) of oxygen saturation by the gasometric tonometer technic gave mean values for adults which on the whole agree well with that of this study. Values found by Gibbs, Lennox, Nims and Gibbs (45) and by Cullen and Cook (46) tend to be lower.
Our results for children tend to be higher than values reported by Preston and Ordway (50) who found a mean value of 93.9 per cent for 14 children 7 to 14 years of age by the RoughtonScholander microgasometric method (51). They agree better with the mean value of 95.3 per cent which Brinkman and Jonxis (52) found for 20 normal children by means of a photoelectric method. These authors found a trend toward slightly lower values, with a mean of 93.6 per cent, in infants between 2 and 7 months of age. Robinson (1) found that arterial saturation varied little with age between 10 and 40 years of age, although after 40 years it tended to decrease slightly. Our results agree with those of Robinson for children over 6 years and for young adults. Robinson did not include data for younger children. 
We have noted a trend toward slightly lower values of arterial oxygen saturation in the very young child. Although this difference is small, consideration of its origin has theoretical interest. Factors which might cause a small difference in arterial saturation involve differences in alveolar oxygen pressure, alveolar-arterial $\mathrm{pO}_{2}$ gradients, and the position or shape of the oxygen dissociation curve.

While the lower arterial saturation of the adult of advanced years may be attributed to an increase in the alveolar-arterial oxygen tension gradient with increasing age $(1,53)$, the assumption of a correspondingly high gradient in the young child does not seem probable. Causes for a high gradient, such as venous admixture from anastomoses in the coronary or pulmonary circulation, areas in the lungs that are perfused but not well ventilated, or a high diffusion gradient for oxygen across the alveolar membrane, are unlikely to appear in the young child to a greater degree than in the older child or the adult.

We have shown in an earlier report (54) that the position of the oxygen dissociation curve is displaced to the right in the child as compared to the adult. The average age of the children studied was under 6 years. If it could be shown that the dissociation curve lies farther to the right in the very young child and gradually moves to the left as the child grows, this would offer a simple explanation for the small difference in arterial saturation which was found. Proof for such a shift in the position of the dissociation curve would be difficult because of the small differences involved and the comparatively large individual variation. A study of a limited number of older children gave no evidence of a return to the adult position.

Under basal conditions the rate of pulmonary ventilation in the young child is higher than it is in the older child. According to Robinson's investigations (1) this is due both to a higher respiratory rate and to a tidal air volume which is high in relation to body size and vital capacity. Using the Haldane end-expiratory method for collecting samples of alveolar air, Robinson found a mean alveolar $\mathrm{pO}_{2}$ of $105 \mathrm{~mm}$. in children 7 to 12 years of age as compared with a mean value of $98 \mathrm{~mm}$. in children of 13 to 15 years. Corresponding values for younger children were not measured, but Robinson noted a higher ventilatory rate in the child of 5 and 6 years as compared with that of the 8 to 12 year old child. Presumably this would lead to a greater rate of alveolar ventilation, a higher alveolar $\mathrm{pO}_{2}$, with subsequently a slightly higher arterial oxygen saturation rather than the lower value found in the present study. It is quite possible that the apparent contradiction lies in the fact that the basal state did not truly exist because crying and a certain amount of struggling could not be avoided in younger children.

The effects of crying cannot be predicted since crying involves varying degrees both of breathholding and of hyperventilation. One tends to compensate the other. In the case of children of 2 and 3 years the acid-base balance of the arterial blood in Figure 3 shows practically no evidence of $\mathrm{CO}_{2}$ excess, characteristic of breathholding, nor of $\mathrm{CO}_{2}$ deficit, characteristic of overventilation. Since crying did occur, it must be presumed that the effects of breathholding have balanced those of hyperventilation, at least so far as the $\mathrm{CO}_{2}$ equilibrium is concerned. However, oxygen is known to diffuse through the alveolar membrane more slowly than $\mathrm{CO}_{2}$, hence it cannot be said with certainty that the breathholding phase of crying has not lowered the arterial saturation by lowering the alveolar oxygen tension.

The effects upon the arterial saturation of the young child due to the physical effort of struggling should also be considered. Evidence in the literature concerning the effect of exercise on arterial saturation is conflicting, but all authors agree that any effect in a normal, healthy adult will be small unless the exercise is severe and fatiguing. Himwich and Barr (55) have shown that the arterial saturation of healthy adults rises slightly during moderate exercise but may decrease if the exercise is severe enough. Riley, Lilienthal, Proemmel, and Franke (56) found arterial saturations of 91.7, 92.5, 95.2 and 93.2 during exercise on the treadmill or bicycle ergometer as compared with three values during rest of 95.2, 95.3 and 98.8. Later, Riley and his collaborators reported similar results with three more normal adults (57). Experiments of Montgomery and his associates (58), in which normal persons 9 to 60 years of age walked on a treadmill at 1.7 M.P.H., showed negligible changes in arterial saturation as measured by the ear oximeter; values ranged from -2.0 to 0 percentage points, with a mean value of 0.3 percentage points. Our own experience, 
using the ear oximeter to determine arterial saturation in healthy children and adults during moderate exercise on the treadmill, leads us to the conclusion that while arterial saturation may decrease by one or two percentage points during the first minute or so of exercise it rises to the resting level or above this when adequate pulmonary and circulatory adaptations are made to meet the increased demand for oxygen. It is possible that these demands were not met at the time that the arterial sample was drawn in the young child.

The triaxial charts of Figure 3 show clearly the acid-base relationships in arterial blood at the different ages of childhood. The good agreement of our data for adults with those of Dill, Edwards and Consolazio (19), which were secured by the same methods, gives confidence that the findings for children are not due to technical errors but represent actual deviations from the adult state. The heavy lines of the chart follow those of Shock and Hastings (18). They represent the pathway of change from the normal, due to respiratory factors which cause $\mathrm{CO}_{2}$ excess or deficit, and to metabolic factors which result in acid or alkali excess or deficit.

By reference to the guide lines it can be seen that the low arterial $\mathrm{CO}_{2}$ content which was found in most of the children of 2 and 3 years is due to metabolic acidosis. In only two cases is there evidence of hyperventilation. Metabolic acidosis may be due to addition of fixed acid to the blood or loss of base from the blood. Experimental data are lacking which could determine which factor is responsible for the acid-base pattern which was observed in the very young child. However, since Kelsey and Leinbach (59) have shown by the conductivity method of Sunderman (60) that mean total base concentrations are higher in children of 2 to 6 years than in older children, excess of acid in the blood appears to be the more probable factor.

It is of interest to consider the possible composition of the acids which may have replaced bicarbonate in the blood serum of the child of 2 to 6 years. We can only conjecture, since anions other than bicarbonate were not determined in children of this age. Of the possible anions it would seem true that only chloride and organic acids could differ from the adult pattern in quantities great enough to balance the decrease in bicarbonate which was observed.
The arterial samples were drawn before the child had breakfast, approximately 16 hours after the meal of the preceding evening. Young children are known to be particularly sensitive to ketogenesis since acetone bodies appear in the urine and breath after comparatively short periods of fasting. It may be possible that the decreased bicarbonate concentration is caused by an increase in ketone acids in the blood. Gamble, Ross, and Tisdall (61) studied changes in acid-base equilibrium during the prolonged periods of fasting which were used as a therapeutic measure in epileptic children and found a marked decrease in both bicarbonate and chloride ions after three or four days of fasting, due to the presence of ketone acids. In experiments of Shaw and Moriarty (62), which followed the changes in alkaline reserve in epileptic children on consecutive days of fasting, the decrease in alkaline reserve did not appear until the second or third day of the fast, although breath acetone was stronger the first day than on those following. On the other hand, Wilson, Levine and Rivkin (63), noted a marked decrease in the $\mathrm{CO}_{2}$ content of the blood of normal children 6 to 12 years of age after 24 to 30 hours of fasting. It has not yet been proven whether or not the tendency to ketosis is marked enough in children of 2 and 3 years to reduce the bicarbonate concentration by an average of $3 \mathrm{mEq}$. per liter after a fast of no more than 17 hours.

Our results agree with those of Robinson (1) in showing an increase in the alkaline reserve or $\mathrm{T}_{40}$ value of the blood with increasing age from early childhood to the adult state. Leenhardt and Chaptal (64) found a similar trend in a study in which the alkaline reserve of the plasma was determined from early infancy to 14 years. Robinson suggested that the lower value in early childhood may represent a compensation to loss of $\mathrm{CO}_{2}$ by overventilation, since his study had shown that young children have very high rates of lung ventilation both in rest and during exercise. A reduced alkaline reserve is known to occur in cases of chronic hyperventilation $(65,66)$ and is also found in the blood of residents at high altitudes $(49,67,68)$. As has been shown, such an explanation is contradicted in the case of the very young children by the position of all but two of their values in the acid-base diagram. As the child grows, the acid-base pattern is shifted in the 
direction of respiratory alkalosis to positions which represent the combined effect of mild hyperventilation and acidosis. The net effect may be considered either a compensated metabolic acidosis or a compensated respiratory alkalosis, depending on which is the primary factor. It would seem reasonable to consider the change with growth as a gradual change in the metabolic processes in the sense that the production of organic acids is reduced and compensation is achieved by the high respiratory rate. A study of the complete electrolyte balance in this age range might test the accuracy of this assumption.

If the rapid respiratory rate of the child under 12 years is the primary factor in the production of a low alkaline reserve, analogy with a state of chronic hyperventilation caused either by disease or by residence at high altitudes suggests that compensation would be achieved chiefly by a rise in serum chloride concentration. Although data concerning the serum chloride concentrations of normal children of all ages are not abundant in the literature, available information gives no evidence that the chloride concentration of children of any age is different from that of the adult. A number of investigators (69-74) have shown that the chloride concentration of the blood serum of the newborn infant tends to be higher than that of the adult, and Marples and Lippard (70) found that a high serum chloride in the newborn balanced a low alkaline reserve, but Overman, Etteldorf, Bass, and Horn (73) observed that after the first day or two of life the plasma chloride concentration decreased and the mean level of $104 \mathrm{mEq}$. per liter in infants of 11 to 26 months was identical with that found by Erickson, Williams, Hummel, and Macy (74) in children 5 to 9 years of age. Robinson (1) found the plasma chloride concentration in arterial blood remarkably constant throughout the entire age range from 8 to 80 years, the average varying only from 104.0 to $105.3 \mathrm{mEq}$. per liter in the various groups.

It is evident that while available data agree that the alkaline reserve of the blood tends to be low in the very young child, and that the adult level is not reached until the age of twelve years or later, a satisfactory explanation of the electrolyte balance must await further experimental work.

\section{SUMMARY}

The blood gases, oxygen saturation and acidbase balance have been determined in arterial blood samples from 41 children of both sexes 2 to 10 years of age, from 63 boys 11 to 17 years of age and from 9 young male adults. All were physically normal and in good health at the time the samples were taken.

From the plotted data certain trends with age were observed; these were analyzed statistically. The results may be summarized as follows:

1. Hemoglobin concentration of the blood, as measured by the oxygen capacity, increases with increasing age from a level of $12.3 \mathrm{G}$. per $100 \mathrm{ml}$. at 2 years to a level of $14.7 \mathrm{G}$. per $100 \mathrm{ml}$. at 15 to 17 years. The mean value for young male adults was found to be $15.8 \mathrm{G}$. per $100 \mathrm{ml}$.

2. A mean percentage arterial oxygen saturation of 94.2 per cent for children of 2 to 4 years is significantly lower than that of 95.8 per cent for children of 7 to 17 years and of 95.9 per cent for young adults.

3. The $\mathrm{CO}_{2}$ content of arterial blood is found to be relatively low in children of 2 and 3 years, with a mean level of 40.1 vol. per cent. In children above 3 years of age the mean level rises gradually from 44.4 vol. per cent at 4 to 6 years to 48.5 vol. per cent in the adult. The alkaline reserve of the blood and plasma shows a similar trend.

4. Arterial $\mathrm{CO}_{2}$ tension increases at 13 years from a previous level of $38 \mathrm{~mm}$. $\mathrm{Hg}$ to the adult level of $41 \mathrm{~mm}$. $\mathrm{Hg}$.

5. The mean $\mathrm{pH}_{\mathrm{s}}$ of arterial blood varies between 7.38 and 7.40 for all age groups except the youngest. A mean $\mathrm{pH}_{8}$ of 7.35 was found in children of 2 and 3 years.

6. In children of 2 and 3 years displacement of the acid-base balance from the adult pattern is shown to be almost entirely in the direction of fixed acid excess or metabolic acidosis. Between 4 and 11 years the acid-base balance appears to be the resultant of slight acid excess and $\mathrm{CO}_{2}$ deficit. In boys of 12 years and over, evidence of acid excess almost disappears and the acid-base pattern is shifted rather toward slight $\mathrm{CO}_{2}$ excess.

7. A study of the electrolyte pattern of the serum in the arterial blood of boys 10 to 17 years of age has shown that, although the bicarbonate concentration rises slightly with increasing age, 
this rise is not balanced by a compensatory reduction in the concentration of chloride, proteinate, phosphate or lactate ions of the serum, nor by a corresponding rise in serum sodium.

\section{ACKNOWLEDGMENT}

The authors gratefully acknowledge the technical assistance of those whose careful work made this study possible: Jeanne Miller, Harold Ziskin, Geraldine Kidd Barbaras, Irving Sheft, June Breidigan Denemark, Lottie Walaszek Piatrowski, Melba Holder, Florence Numajiri Field, Edna O'Connell and Axel Swanson.

They also wish to express their deep appreciation and thanks to Dr. D. B. Dill, formerly of the Fatigue Laboratory at Harvard University, and at present Scientific Director, Medical Division, Army Chemical Center, Maryland, and to Dr. Sid Robinson of the Department of Physiology, University of Indiana, for inspiration and for aid in problems both of technique and of calculation of the acid-base data.

\section{REFERENCES}

1. Robinson, S., Experimental studies of physical fitness in relation to age. Arbeitsphysiol., 1938, 10, 251.

2. Morse, M., Cassels, D. E., and Schultz, F. W., Available and interstitial fluid volumes of normal children. Am. J. Physiol., 1947, 151, 438.

3. Morse, M., Cassels, D. E., and Schlutz, F. W., Blood volumes of normal children. Am. J. Physiol., 1947, 151, 448.

4. Morse, M., Schlutz, F. W., and Cassels, D. E., Relation of age to physiological responses of the older boy (10-17 years) to exercise. .J. Applied Physiol., 1949, 1, 683.

5. Morse, M., Schlutz, F. W., and Cassels, D. E., The lung volume and its subdivisions in normal boys 10-17 years of age. J. Clin. Invest., 1952, 31, 380.

6. Van Slyke, D. D., and Neill, J. M., The determination of gases in blood and other solutions by vacuum extraction and manometric measurement. I. J. Biol. Chem., 1924, 61, 523.

7. Roughton, F. J. W., Darling, R. C., and Root, W. S., Factors affecting the determination of oxygen capacity, content and pressure in human arterial blood. Am. J. Physiol., 1944, 142, 708.

8. Horvath, S. M., Consolazio, W. V., and Dill, D. B., Syllabus of Methods of the Fatigue Laboratory. Harvard University, 1942.

9. Ma, T. S., and Zuazaga, G., Micro-Kjeldahl determination of nitrogen. $A$ new indicator and an improved rapid method. Indust. \& Engin. Chem. (Anal. Ed.), 1942, 14, 280.

10. Sendroy, J., Jr., Microdetermination of chloride in biological fluids, with solid silver iodate. I. Gasometric analysis. J. Biol. Chem., 1937, 120, 335. II. Titrimetric analysis. Ibid., 405.

11. Fiske, C. H., and Subbarrow, Y., The colorimetric determination of phosphorus. J. Biol. Chem., 1925, 66, 375.
12. Edwards, H. T., A simplified estimation of lactate in normal human serum. J. Biol. Chem., 1938, 125 , 571.

13. Friedemann, T. E., Cotonio, M., and Shaffer, P. A., The determination of lactic acid. J. Biol. Chem., 1927, 73, 335.

14. Consolazio, W. V., and Dill, D. B., The determination of sodium. J. Biol. Chem., 1941, 137, 587.

15. Butler, A. M., and Tuthill, E., An application of the uranyl zinc acetate method for determination of sodium in biological material. J. Biol. Chem., 1931, 93, 171.

16. Van Slyke, D. D., Hastings, A. B., Hiller, A., and Sendroy, J., Jr., Studies of gas and electrolyte equilibria in blood. XIV. The amounts of alkali bound by serum albumin and globulin. J. Biol. Chem., 1928, 79, 769.

17. Hastings, A. B., and Steinhaus, A. H., A new chart for the interpretation of acid-base changes and its application to exercise. Am. J. Physiol., 1931, 96, 538.

18. Shock, N. W., and Hastings, A. B., Studies of the acid-base balance of the blood. IV. Characterization and interpretation of displacement of the acidbase balance. J. Biol. Chem., 1935, 112, 239.

19. Dill, D. B., Edwards, H. T., and Consolazio, W. V., Blood as a physicochemical system. XI. Man at rest. J. Biol. Chem., 1937, 118, 635.

20. Mugrage, E. R., and Andresen, M. I., Red blood cell values in adolescence. Am. J. Dis. Child., 1938, 56, 997.

21. Mugrage, E. R., and Andresen, M. I., Values for red blood cells of average infants and children. Am. J. Dis. Child., 1936, 51, 775.

22. Depner, M., Ergebnisse der Hämoglobin- und Serumeiweissbestimungen im Rahmen der Reihenuntersuchungen in Hessen. Klin. Wchnschr., 1950, 28, 441.

23. Kaucher, M., Moyer, E. Z., Harrison, A. P., Thomas, R. U., Rutledge, M. M., Lameck, W., and Beach, E. F., Nutritional status of children. VII. Hemoglobin. J. Am. Dietet. A., 1948, 24, 496.

24. Hawkins, W. W., Leeson, H. J., and McHenry, E. W., Haemoglobin levels in Canadian population groups: children and young women. Canad. M. A. J., 1947, 56, 502.

25. Pett, L. B., and Ogilvie, G. F., Haemoglobin levels at different ages. Canad. M. A. J., 1948, 58, 353.

26. The Committee on Haemoglobin Surveys, Haemoglobin levels in Great Britain in 1943 (with observations upon serum protein levels). Medical Research Council, Special Report Series No. 252, His Majesty's Stationary Office, London, 1945.

27. Hamre, C. J., and Au, M. H., Hematologic values for normal healthy men 16 to 25 years of age. J. Lab. \& Clin. Med., 1942, 27, 1231.

28. Mack, P. B., Smith, J. M., Logan, C. H., O'Brien, A. T., Shaw, J. J., and Dodds, P., Hemoglobin values in Pennsylvania mass studies in human nutrition. Milbank Mem. Fund, 1941, 19, 282. 
29. Wiehl, D. G., Medical evaluation of nutritional status. III. Hemoglobin and erythrocyte values for adolescents in high-income families. Milbank Mem. Fund, 1941, 19, 45.

30. McNamara, H., and Senn, M. J. E., Glutathione and red cells in the blood in infancy and childhood. Am. J. Dis. Child., 1940, 59, 97.

31. Hawkins, W. W., and Kline, D. K., Hemoglobin levels among seven to fourteen year old children in Saskatoon, Canada. Blood, 1950, 5, 278.

32. Fysh, C. F., Hemoglobin determinations of 1265 Bunbury school children and of a small group of adults. M. J. Australia, 1950, 37 (2), 508.

33. Guest, G. M., Brown, E. W., and Wing, M., Erythrocytes and hemoglobin of the blood in infancy and in childhood. II. Variability in number, size and hemoglobin content of the erythrocytes during the first five years of life. Am. J. Dis. Child., 1938, $56,529$.

34. Osgood, E. E., Normal hematologic standards. Arch. Int. Med., 1935, 56, 849.

35. Wilke, E., Uber den Gehalt des Blutes gesunder Kinder vom zweiten bis vierzehnten Lebensjahr an roten Blutkörperchen, an Blutfarbstoff, an Retikulocyten und an Thrombocyten. Folia haemat., 1934, 52, 291.

36. Borchers, J., Das rote Blutbild gesunder Jugendlicher männlichen Gesehlechtes im Alter von 13 bis 20 Jahren. Folia haemat., 1936, 54, 387.

37. Williamson, C. S., Influence of age and sex on hemoglobin: A spectrophotometric analysis of nine hundred and nineteen cases. Arch. Int. Med., 1916, 18, 505.

38. Peters, J. P., and Van Slyke, D. D., Quantitative Clinical Chemistry; Vol. I Interpretations. Williams and Wilkins Co., Baltimore, 1932, p. 543.

39. Widdowson, E. M., and McCance, R. A., Effect of rest in bed on plasma volume as indicated by haemoglobin and haemotocrit levels. Lancet, 1950, $1,539$.

40. Drabkin, D. L., and Schmidt, C. F., Spectrophotometric studies. XII. Observation of circulating blood in vivo, and the direct determination of the saturation of hemoglobin in arterial blood. J. Biol. Chem., 1945, 157, 69.

41. Comroe, J. H., Jr., and Walker, P., Normal human arterial oxygen saturation determined by equilibration with 100 per cent $\mathrm{O}_{2}$ in vivo and by the oximeter. Am. J. Physiol., 1948, 152, 365.

42. Wood, E. H., Normal oxygen saturation of arterial blood during inhalation of air and oxygen. $\mathrm{J}$. Appl. Physiol., 1949, 1, 567.

43. Keys, A., and Snell, A. M., Respiratory properties of the arterial blood in normal man and in patients with disease of the liver: position of the oxygen dissociation curve. J. Clin. Invest., 1938, 17, 59.

44. Looney, J. M., and Jellinek, E. M., The oxygen and carbon dioxide content of the arterial and venous blood of normal subjects. Am. J. Physiol., 1937, $118,225$.

45. Gibbs, E. L., Lennox, W. G., Nims, L. F., and Gibbs, F. A., Arterial and cerebral venous blood; arterialvenous differences in man. J. Biol. Chem., 1942, $144,325$.

46. Cullen, S. C., and Cook, E. V., Normal human arterial oxygen tension. Am. J. Physiol., 1942, 137, 238.

47. Harvard Fatigue Laboratory, Unpublished observations. Quoted by Roughton, F. J. W., Darling, R. C., and Root, W. S. (7).

48. Cournand, A., Riley, R. L., Breed, E. S., Baldwin, E. deF., and Richards, D. W., Jr., Measurement of cardiac output in man in using the technique of catheterization of the right auricle or ventricle. J. Clin. Invest., 1945, 24, 106.

49. Hurtado, A., and Aste-Salazar, H., Arterial blood gases and acid-base balance at sea level and at high altitudes. J. Appl. Physiol., 1948, 1, 304.

50. Preston, S. N., and Ordway, N. K., Observations of arterial oxygen content in children during the inhalation of air and 100 per cent oxygen. Am. J. Physiol., 1948, 152, 696.

51. Roughton, F. J. W., and Scholander, P. F., Microgasometric estimation of the blood gases. I. Oxygen. J. Biol. Chem., 1943, 148, 541.

52. Brinkman, R., and Jonxis, J. H. P., Estimation of arterial unsaturation, especially in pediatric conditions. Acta med. Scandinav., 1938, 94, 453.

53. Dill, D. B., Graybiel, A., Hurtado, A., and Taquini, A. C., Der Gasaustausch in den Lungen im Alter. Ztschr. f. Altersforschung, 1940, 2, 20.

54. Morse, Minerva, Cassels, D. E., and Holder, M., The position of the oxygen dissociation curve of the blood in normal children and adults. J. Clin. Invest., 1950, 29, 1091.

55. Himwich, H. E., and Barr, D. P., Studies in the physiology of muscular exercise. V. Oxygen relationships in the arterial blood. J. Biol. Chem., 1923, 57, 363.

56. Riley, R. L., Lilienthal J. L., Proemmel, D. D., and Franke, R. E., The relationships of oxygen, carbon dioxide, and hemoglobin in the blood of man: oxyhemoglobin dissociation under various physiological conditions. J. Clin. Invest., 1946, 25, 139.

57. Riley, R. L., Himmelstein, A., Motley, H. L., Weiner, H. M., and Cournand, A., Studies of the pulmonary circulation at rest and during exercise in normal individuals and in patients with chronic pulmonary disease. Am. J. Physiol., 1948, 152, 372.

58. Montgomery, G. E., Wood, E. H., Burchell, H. B., Dry, T. J., Parker, R. L., and Helmholz, H. F., Jr., Continuous observations of the arterial oxygen saturation at rest and during exercise in congenital heart disease. Am. Heart J., 1948, 36, 668.

59. Kelsey, W. M., and Leinbach, L. B., Observations of total serum base in children and young adults by a conductivity method. Pediatrics, 1949, 4, 805. 
60. Sunderman, F. W., Studies in serum electrolytes. XIV. Changes in blood and body fluids in prolonged fasting. Am. J. Clin. Path., 1947, 17, 169.

61. Gamble, J. L., Ross, G. S., and Tisdall, F. F., The metabolism of fixed base during fasting. J. Biol. Chem., 1923, 57, 633.

62. Shaw, E. B., and Moriarty, M., Hypoglycemia and acidosis in fasting children with idiopathic epilepsy. Am. J. Dis. Child., 1924, 28, 553.

63. Wilson, J. R., Levine, S. Z., and Rivkin, H., The respiratory metabolism in infancy and childhood. II. Ketosis and the respiratory exchange in children. Am. J. Dis. Child., 1926, 31, 335.

64. Leenhardt, E., and Chaptal, J., La réserve alcaline du sang du nourrison et de l'enfant: sa valeur et ses variations physiologiques. Rev. franc. de pediat., 1927, 3, 641.

65. Peters, J. P., Bulger, H. A., Eisenman, A. J., and Lee, C., Total acid-base equilibrium of plasma in health and disease. IV. The effects of stasis, exercise, hyperpnea, and anoxemia; and the causes of tetany. J. Biol. Chem., 1926, 67, 175.

66. Talbott, J. H., Cobb, S., Coombs, F. S., Cohen, M. E., and Consolazio, W. V., Acid-base balance of the blood in a patient with hysterical hyperventilation. Arch. Neurol. \& Psychiat., 1938, 39, 973.

67. Dill, D. B., Edwards, H. T., Fölling, A., Oberg, S. A.,
Pappenheimer, A. M., Jr., and Talbott, J. H. Adaptations of the organism to changes in oxygen pressure. J. Physiol., 1931, 71, 47.

68. Dill, D. B., Talbott, J. H., and Consolazio, W. V., Blood as a physicochemical system. XII. Man at high altitudes. J. Biol. Chem., 1937, 118, 649.

69. Hoag, L. A., and Kiser, W. H., Jr., Acid-base equilibrium of newborn infants. I. Normal standards. Am. J. Dis. Child., 1931, 41, 1054.

70. Marples, E., and Lippard, V. W., Acid-base balance of newborn infants. II. Consideration of low alkaline reserve of normal newborn infants. Am. J. Dis. Child., 1932, 44, 31.

71. McCance, R. A., and Young, W. F., Secretion of urine by newborn infants. J. Physiol., 1941, 99, 265.

72. Darling, R. C., Smith, C. A., Asmussen, E., and Cohen, F. M., Some properties of human fetal and maternal blood. J. Clin. Invest., 1941, 20, 739.

73. Overman, R. R., Etteldorf, J. N., Bass, A. C., and Horn, G. B., Plasma and erythrocyte chemistry of the normal infant from birth to two years of age. Pediatrics, 1951, 7, 565.

74. Erickson, B. N., Williams, H. H., Hummel, F. C., and Macy, I. G., Lipid and mineral distribution in serum and erythrocytes of normal children. $J$. Biol. Chem., 1937, 118, 15. 